\title{
COVID-19 and dental aerosols: The infection connection
}

The present global COVID-19 outbreak really constituted a big public health emergency. ${ }^{[1]}$ This novel human coronavirus, now named severe acute respiratory syndromecoronavirus-2 (SARS-CoV-2), has been first detected in Wuhan, Hubei, China, in late 2019. ${ }^{[2]}$ Increased deaths in humans have been reported because of the infection of either SARS-CoV-2 or the Middle East respiratory syndrome coronavirus (MERS-CoV). ${ }^{[3-5]}$

SARS-CoV-1 was the main causative agent of the SARS outbreaks in 2002 and 2003 in Guangdong Province, China. ${ }^{[6]}$ Due to relative inefficient transmission of SARS-CoV-1, its outbreak was controllable through quarantining of affected individuals in households and healthcare centers. ${ }^{[7]}$ Comparatively, SARS-CoV-2 is just like SARS-CoV- 1 with an $80 \%$ genetic makeup similarity. However, SARS-CoV-2affected individuals have shown higher viral loads in nasal and upper respiratory passages, indicating coughs and sneezes contained higher viral loads than SARS-CoV- $1 .{ }^{[5]}$ This new virus strain is much more efficient at traveling more considerable distances and becoming aerosolized. ${ }^{[8]}$

COVID-19 was being reported to be detected in saliva of the infected patients that is suggestive enough for dental/ oral and other professionals to show extra care and effort in protection against the spread of this disease. ${ }^{[9]}$ Even though, the other transmission routes of COVID-19 are not confirmed yet, but its human-to-human spread has been determined. ${ }^{[10,11]}$ Expectorated sputum can be considered as specimen for laboratory diagnostic test in severe respiratory disease. $^{[2,12,13]}$

Aerosol particles are classified, based on size, as coarse $(2.5-10 \mu \mathrm{m})$, fine $(<2.5 \mu \mathrm{m})$, and ultrafine $(<0.1 \mu \mathrm{m})$. The nose filters air particles above $10 \mu \mathrm{m}$, so coarse particles can easily enter the respiratory tract. Fine particles can enter the alveoli, and ultrafine particles like the COVID-19 virus can enter the bloodstream and target organs such as the heart and brain. The current scientific consensus is that most transmission via respiratory secretions happens in the form of large respiratory droplets rather than small aerosols. Droplets are often heavy enough that they do not travel very far; instead, they fall from the air after traveling up to $6 \mathrm{ft}$. The problem occurs when viral particles are aerosolized by a cough, sneeze, or dental care. In these instances, particles can potentially travel across far greater distances, which estimate up to $20 \mathrm{ft}$, from an infected person and then incite secondary infections elsewhere in the environment. These aerosolized droplet nuclei can remain in an area, suspended in the air, even after the person who emitted them has left and thus can infect healthcare workers and contaminate surfaces.

Viability of COVID-19 in various places is up to $72 \mathrm{~h}$ after application to plastic and stainless steel surfaces, up to $24 \mathrm{~h}$ on cardboard surfaces, up to $9 \mathrm{~h}$ on copper surfaces, and up to $3 \mathrm{~h}$ in suspended aerosols. ${ }^{[14]}$ There is some evidence that COVID-19 infection may lead to intestinal infection and be present in feces. However, to date, only one study has cultured the COVID-19 virus from a single stool specimen. There have been no reports of fecal-oral transmission of the COVID-19 virus to date. ${ }^{[15]}$ Viral loads in nasopharyngeal swabs from a group of patients with severe COVID-19 were 60 times higher on average than the viral loads seen among patients with a mild form of the disease. ${ }^{[16]}$ This raises a serious question about posing dental aerosolization as an additional threat for outbreaks of COVID-19.

Many dental procedures that are performed using a variety of high-speed dental turbines, micro-motor hand pieces, ultrasonic scalers, laser or electrosurgery units, air polishers, prophy angles, hand instrumentation, and air/water syringes can generate bioaerosols and splatter. ${ }^{[17,18]}$ Bioaerosol contain blood, microorganisms, mucosal cells, restorative materials, tooth particles, and large quantities of saliva. ${ }^{[19]}$ Dental professionals treating patients using aerosolization are at an extremely dangerous risk of inoculation of themselves, their team workers and staff, and reinoculation of the patients. This risk is mostly applied to the midface of the dentist and assistant, as well as the nasal area of the patient. ${ }^{[20]}$ Periodontal procedures has higher incidence of droplet transmission than prosthetic treatment. ${ }^{[21]}$ Ultrasonic and sonic transmission during nonsurgical procedures had the highest incidence of particle transmission, followed by air polishing, air/water syringe, and high-speed hand-piece aerosolization. ${ }^{[17]}$ Ultrasonic instrumentation can transmit 100,000 microbes per cubic foot with aerosolization of up to $6 \mathrm{ft}$ and, in the absence of adequate air ventilation, these microbes can be viable anywhere from $35 \mathrm{~min}$ to $17 \mathrm{~h} \cdot{ }^{[22]}$ Dental professionals are exposed to up to $1.86 \mathrm{E}+05$ 
bacteria/m $\mathrm{m}^{3}$ of air. ${ }^{[23]}$ In view of COVID-19 outbreak and inherent dangers to dental professionals, the Occupational Safety and Health Act (OSHA) released a new report "Guidance on Preparing Workplaces for COVID-19" that categorizes occupations involved with aerosolization as very high-risk category. ${ }^{[24]}$

Small droplets can result in long-distance transmission, whereas large droplet could do it to nearby subjects. ${ }^{[25]}$ Unknowingly, dental professionals may provide dental care to those who are infected or suspected, but not yet diagnosed with COVID-19. ${ }^{[12,13]}$ Thus, many patients can be asymptomatic spreading infection before the disease symptoms appear within then. ${ }^{[26]}$ Hence, it is really crucial for dental professionals to refine preventive strategies to avoid COVID-19 infection by focusing on patient placement, hand hygiene, all personal protective equipment, and caution in performing aerosol-generating dental procedures.

\section{Financial support and sponsorship}

Nil.

\section{Conflicts of interest}

There are no conflicts of interest.

Suryakant C. Deogade, Dinesh Naitam

Department of Prosthodontics and Crown \& Bridge, Government Dental College \& Hospital, Nagpur, Maharashtra, India, ' Department of Dentistry, Government Medical College and Hospital, Akola, Maharashtra, India

Address for correspondence: Dr. Suryakant C. Deogade, Shivgiri- 404, Himalaya Empire Cooperative Society, Fulmatai Lay Out, Babulkheda, Nagpur, Maharashtra 440027, India.

Email:dr_deogade@yahoo.co.in

\section{RefERENCES}

1. The Lancet. Emerging understandings of COVID-19. Lancet 2020;395:311. https://doi.org/10.1016/S0140-6736 (20) 30186-0.

2. Zhu N, Zhang D, Wang W, Li X, Yang B, Song J. A Novel Coronavirus from Patients with Pneumonia in China, 2019. N Engl J Med 2020;382:727-33.

3. Hui DSC, Zumla A. Severe acute respiratory syndrome: Historical, epidemiologic, and clinical features. Infect Dis Clin North Am 2019;33:869-89.

4. de Groot RJ, Baker SC, Baric RS, Brown CS, Drosten C, Enjuanes L, et al. Middle east respiratory syndrome coronavirus (MERS-cov): Announcement of the coronavirus study group. J Virol 2013;87:7790-2.

5. Ksiazek TG, Erdman D, Goldsmith CS, Zaki SR, Peret T, Emery S, et al.; SARS Working Group. A novel coronavirus associated with severe acute respiratory syndrome. N Engl J Med 2003;348:1953-66.

6. Drosten C, Günther S, Preiser W, van der Werf S, Brodt HR, Becker S, et al. Identification of a novel coronavirus in patients with severe acute respiratory syndrome. N Engl J Med 2003;348:1967-76.
7. Peiris JS, Yuen KY, Osterhaus AD, Stöhr K. The severe acute respiratory syndrome. N Engl J Med 2003;349:2431-41.

8. Bai Y, Yao L, Wei T, Tian F, Jin D, Chen L. Presumed Asymptomatic Carrier Transmission of COVID-19. JAMA 2020;323:1406-7.

9. To KK, Tsang OT, Yip CC, Chan K, Wu T, Chan J, et al. Consistent detection of 2019 novel coronavirus in Saliva. Clinical Infectious Diseases 71;15:841-3. https://doi.org/10.1093/cid/ciaa149.

10. Wu A, Peng Y, Huang B, Ding X, Wang X, Niu P, et al. Genome Composition and Divergence of the Novel Coronavirus (2019-nCoV) Originating in China. Cell Host Microbe 2020;27:325-8.

11. Shu Y, McCauley J. GISAID: Global initiative on sharing all influenza data - From vision to reality. Euro Surveill 2017;22:1-3. https:// doi. org/10.2807/1560-7917.ES.2017.22.13.30494

12. ECDC - European Centre for Disease Prevention and Control; European surveillance for human infection with novel coronavirus (COVID-19). Accessed 28 January 2020. Available at: https://www.ecdc.europa. eu/en/european-surveillance-humaninfection-novel-coronavirusCOVID-19

13. World Health Organization-WHO (2020) Global surveillance for human infection with novel coronavirus (COVID-19) Interim guidance. Accessed 28 January 2020. Available at: https://www.who.int/docs/ default-source/coronaviruse/20200121-global surveillance-forCOVID-19.pdf

14. Doremalen NV, Bushmaker T, Morris DH, Holbrook MG, Gamble A, Williamson BN, et al. Aerosol and Surface Stability of SARS-CoV-2 as Compared with SARS-CoV-1. N Engl J Med 2020;382:1564-7.

15. Zhang Y, Chen C, Zhu S, Shu C. Isolation of 2019-nCoV from a Stool Specimen of a Laboratory-Confirmed Case of the Coronavirus Disease 2019 (COVID-19). China CDC Weekly 2:123-4.

16. Verity R, Okell LC, Dorigatti I, Winskill P, Whittaker C, Imai N, et al. Estimates of the severity of coronavirus disease 2019: A model-based analysis. Lancet Infect Dis 2020;20:669-77. doi: 10.1016/S14733099(20)30243-7.

17. Harrel SK, Molinari J. Aerosols and splatter in dentistry: A brief review of the literature and infection control implications. J Am Dent Assoc 2004;135:429-37.

18. Hallier C, Williams DW, Potts AJ, Lewis MA. A pilot study of bioaerosol reduction using an air cleaning system during dental procedures. $\mathrm{Br}$ Dent J 2010;209:E14.

19. Zemouri C, de Soet H, Crielaard W, Laheij A. A scoping review on bio-aerosols in healthcare and the dental environment. PLoS One 2017;12:e0178007.

20. Nejatidanesh F, Khosravi Z, Goroohi H, Badrian H, Savabi O. Risk of contamination of different areas of dentist's face during dental practices. Int J Prev Med 2013;4:611-5.

21. Williams GH III, Pollok NL III, Shay DE, Barr CE. Laminar air purge of microorganisms in dental aerosols: Prophylactic procedures with the ultrasonic scaler. J Dent Res 1970;49:Suppl:1498+.

22. Miller RL. Characteristics of blood-containing aerosols generated by common powered dental instruments. Am Ind Hyg Assoc J 1995;56:670-6.

23. Dutil S, Veillette M, Mériaux A, Lazure L, Barbeau J, Duchaine C. Aerosolization of mycobacteria and legionellae during dental treatment: Low exposure despite dental unit contamination. Environ Microbiol 2007;9:2836-43.

24. Guidance on Preparing Workplaces for COVID-19. US Department of Labor. Occupational Safety and Health Administration; 2020.

25. Xie X, Li Y, Sun H, Liu L. Exhaled droplets due to talking and coughing. J R Soc Interface 2009;6(Suppl 6):S703-14.

26. Chan JF, Yuan S, Kok K, To KK, Chu H, Yang J, et al. A familial cluster of pneumonia associated with the 2019 novel coronavirus indicating person-to-person transmission: A study of a family cluster. Lancet 2020;395:514-23. 
This is an open access journal, and articles are distributed under the terms of the Creative Commons Attribution-NonCommercial-ShareAlike 4.0 License, which allows others to remix, tweak, and build upon the work non-commercially, as long as appropriate credit is given and the new creations are licensed under the identical terms.

For reprints contact: reprints@ medknow.com

\begin{tabular}{|l|l|}
\hline \multicolumn{2}{|c|}{ Access this article online } \\
\hline Quick Response Code: & \\
\hline & Website: www.avicennajmed.com \\
\cline { 2 - 2 } & \\
\hline
\end{tabular}

Cite this article as: Deogade SC, Naitam DM. COVID-19 and dental aerosols: The infection connection. Avicenna J Med 2021;11:107-9. 